\title{
Impact of Viscosity of Motor Oil on the Wear of Plain Bearings
}

Martin Pexa, Zdeněk Aleš, Jindřich Pavlů, Jakub Čedík

Faculty of Engineering, Czech University of Life Sciences Prague, Department for Quality and Dependability of Machines, Kamýcká 129, 16521 Prague 6 - Suchdol, Czech Republic, E-mail: pexa@tf.czu.cz, ales@tf.czu.cz, pavluj@tf.czu.cz,cedik.jakub@seznam.cz

Manufactures of automotive engines and complete vehicles strive for the lowest possible fuel consumption, which also leads to the use of motor oils with lower viscosity. Lower viscosity of oil reduces internal friction and provides faster distribution of oil into lubrication points, but simultaneously reduces the size of transmitted power. The design of automotive engines use plain bearings, which are based on aluminium, brass. Further are used steels with coating based on aluminium and bronze. The paper describes the impact of viscosity of motor oil to wear of basic materials, which are used in production of plain bearing. Reichert tester M2 for evaluation the lubricity from Petrotest Company was used in order to assess ability of motor oils to create proper lubricating film. Reichert tester M2 belongs to a group of equipments simulating real frictional contact. Stabinger viscometer was also used for the precise determination of viscosity of various types of motor oils.

Keywords: Aluminium alloy, Motor oil, Viscosity, Wear

\section{Acknowledgement}

Paper was created with the grant support - CZU CIGA 2015 - 20153001 - Use of butanol in internal combustion engines.

\section{References}

[1] DOHNER, B., MiChlbERGER, A., CASTANIEN, C., GAJANAYAKE, A., HIROSE, S. (2013). Improving Fuel Efficiency of Motorcycle Oils. In: SAE International Journal of Fuels and Lubricants, 6 (3), ISSN: 19463952

[2] FONTARAS, G., VOUITSIS, E., SAMARAS, Z. (2009). Experimental evaluation of the fuel consumption and emissions reduction potential of low viscosity lubricants. In: SAE Technical Papers.

[3] TAYLOR, R.I., DIXON, R.T., WAYŃE, F.D., GUNSEL, S. (2005). Lubricants \& energy efficiency: Life-cycle analysis. In: Tribology and Interface Engineering Series, 48, pp. 565-572. ISSN: 1572-3364

[4] ATTARD, N. (2014). Volkswagen XL1 priced at £98,515 - 30 coming to UK, Magazine Car online]. [cit. 201508-26]. Dostupné z: http://www.carmagazine.co.uk/car-news/industry-news/volkswagen/volkswagen-xl1-pricedat-98515---30-coming-to-uk/

[5] NOVA, I., MACHUTA, J. (2014). Monitoring methods the properties and structure of grey steel castings. In: Manufacturing Technology, 14 (2), pp. 223-228. ISSN: 1213-2489

[6] WALCZAK, M., PIENIAK, D., ZWIERZCHOWSKI, M. (2015). The tribological characteristics of SiC particle reinforced aluminium composites. In: Archives of Civil and Mechanical Engineering, 15 (1), pp. 116-123. ISSN: $1644-9665$

[7] GUO, Q.Q., LI, J.P. (2015). Microstructure and properties of AlSn20 coating deposited via magnetron sputtering. In: Materials Science Forum, 816, pp. 277-282. ISSN: 0255-5476

[8] AIT-SADI, H., HEMMOUCHE, L., HATTALI, L., BRITAH, M., IOST, A., MESRATI, N. (2015). Effect of nanosilica additive particles on both friction and wear performance of mild steel/CuSn/SnBi multimaterial system. In: Tribology International, 90, pp. 372-385. ISSN: 0301-679X

[9] BAIR, S. (2015). The First Normal Stress Difference in a Shear-Thinning Motor Oil at Elevated Pressure. In: Tribology Transactions, 58 (4), pp. 654-659. ISSN: 1040-2004

[10]SINGH, A.K., SINGH, R.K. (2012). A search for ecofriendly detergent/dispersant additives for vegetable-oil based lubricants. In: Journal of Surfactants and Detergents, 15 (4), pp. 399-409. ISSN: 1097-3958

[11]MAHMOUD, S.A., DARDIR, M.M. (2011). Synthesis and evaluation of a new cationic surfactant for oil-well drilling fluid. In: Journal of Surfactants and Detergents, 14 (1), pp. 123-130. ISSN: 1097-3958

[12] KUMBAR, V., GLOS, J., VOTAVA, J. (2014). Monitoring of chemical elements during lifetime of engine oil. In: Acta Universitatis Agriculturae et Silviculturae Mendelianae Brunensis, 62 (1), pp. 155-159. ISSN: 1211-8516 
[13]PETRASEK, S., MULLER, M. (2014). Setting of angle of soil flow on ploughshare at traditional processing of soil. In: Manufacturing Technology, 14 (3), pp. 407-412. ISSN: 1213-2489

[14]CIESLAR, J., BROZEK, M., BEDNAR, B. (2013). An experimental assessment of special metal castings in reducing abrasive wear. In: Manufacturing Technology, 13 (4), pp. 423-428. ISSN: 1213-2489

[15]VALASEK, P., MULLER, M. (2012). Influence of bonded abrasive particles size on wear of polymeric particle composites based on waste. In: Manufacturing Technology, 12 (13), ISSN: 1213-2489

[16] ANTON PAAR. Viskozimetr podle Stabingera. Stabinger Messtechnik - vyvinuto ve spolupráci s LaborfürMesstechnik Dr. H. Stabinger GmbH, Graz. [online][cit. 2014-06-16]. Dostupné z:http://www.antonpaar.com $/$ ?eID $=$ documentsDownload $\&$ document $=53280 \& \mathrm{~L}=4$

[17]SEJKOROVA, M. Metody tribotechnické diagnostiky. 1. Vyd. Vysoká škola báňská - Technická univerzita Ostrava/Univerzita Pardubice, 2013, 111s. CZ.1.07/2.2.00/15.0462.ISBN: 978-80-248-3280-7. 